\title{
U-Pb Dating and Hf Isotopes Analysis of Detrital Zircons of the Shanxi Formation in the Otuokeqi Area, Northwestern Ordos Basin
}

\author{
Jiaxuan Song $\mathbb{D},{ }^{1}$ Hujun Gong $\mathbb{D}^{1},{ }^{1}$ Jingli Yao, ${ }^{2}$ Huitao Zhao, ${ }^{2}$ Xiaohui Zhao, ${ }^{2}$ \\ Yunxiang Zhang ${ }^{1},{ }^{1}$ and Biao Chen ${ }^{3}$ \\ ${ }^{1}$ State Key Laboratory of Continental Dynamics, Department of Geology, Northwest University, Xi'an, 710069 Shaanxi, China \\ ${ }^{2}$ Exploration \& Development Research Institute of PetroChina Changqing Oilfield Company, Xi'an 710018, China \\ ${ }^{3}$ State Key Laboratory of Baiyunobo Rare Earth Resource Researches and Comprehensive Utilization, Baotou Research Institute of \\ Rare Earths, Baotou 014030, China
}

Correspondence should be addressed to Hujun Gong; hujungong@163.com

Received 3 January 2021; Revised 12 January 2021; Accepted 3 February 2021; Published 26 February 2021

Academic Editor: Feng Xiong

Copyright (c) 2021 Jiaxuan Song et al. This is an open access article distributed under the Creative Commons Attribution License, which permits unrestricted use, distribution, and reproduction in any medium, provided the original work is properly cited.

\begin{abstract}
The Paleozoic strata are widely distributed in the northwest of the Ordos Basin, and the provenance attributes of the basin sediments during this period are still controversial. In this paper, the detrital zircon LA-MC-ICPMS U-Pb age test was conducted on the drilling core samples of the Shanxi Formation of the Upper Paleozoic in the Otuokeqi area of the Ordos Basin, and the provenance age and the characteristic of the Shanxi formation in the Otuokeqi area in the northwest were discussed. The cathodoluminescence image shows that the detrital zircon has a clear core-edge structure, and most of the cores have clear oscillatory zonings, which suggests that they are magmatic in origin. Zircons have no oscillatory zoning structure that shows the cause of metamorphism. The age of detrital zircon is dominated by Paleoproterozoic and can be divided into four groups, which are 2500 2300 Ma, 2100 1600 Ma, 470 400 Ma, and 360 260 Ma. The first two groups are the specific manifestations of the Precambrian Fuping Movement (2.5 billion years) and the Luliang Movement (1.8 billion years) of the North China Craton. The third and fourth groups of detrital zircons mainly come from Paleozoic magmatic rocks formed by the subduction and collision of the Siberian plate and the North China plate. The $\varepsilon \operatorname{Hf}(t)$ value of zircon ranges from - 18.36 to 4.33 , and the age of the second-order $\mathrm{Hf}$ model $T_{\mathrm{DM} 2}$ ranges from 2491 to $1175 \mathrm{Ma}$. The source rock reflecting the provenance of the sediments comes from the material recycling of the Paleoproterozoic and Mesoproterozoic in the crust, combined with the Meso-Neoproterozoic detrital zircons discovered this time, indicating that the provenance area has experienced Greenwellian orogeny.
\end{abstract}

\section{Regional Geology}

The Ordos Basin is a typical craton basin that belongs to the southern part of the North China Craton. It merges with the Yinshan block in the north at $\sim 1.95 \mathrm{Ga}$ along the Kongziite belt to form the western block. After that, around $1.85 \mathrm{Ga}$, the eastern and western continental segments were merged into a unified North China landmass (Zhao et al., 2002; [1]). As can be seen in Figure 1, it is adjacent to the Qinling-Qilian Mountains in the south, the Central North China Orogenic Belt in the east, and the Helan Shan-
Zhuozi Shan in the west. According to the current structural characteristics, it is divided into 6 structural units, including the western margin thrust belt, Tianhuan depression, Yimeng uplift, Weibei uplift, northern Shaanxi slope, and flexure belt in western Shanxi (Yang Junjie and Pei Xigu, 1996). The surrounding strata of the Ordos Basin are mainly ancient metamorphic rock series composed of various metavolcanic-sedimentary rocks of the Proterozoic (Wei Honghong, 2002). The Late Paleozoic strata are widely distributed in the northwestern part of Ordos Basin. The Upper Paleozoic strata developed Upper Carboniferous Benxi 


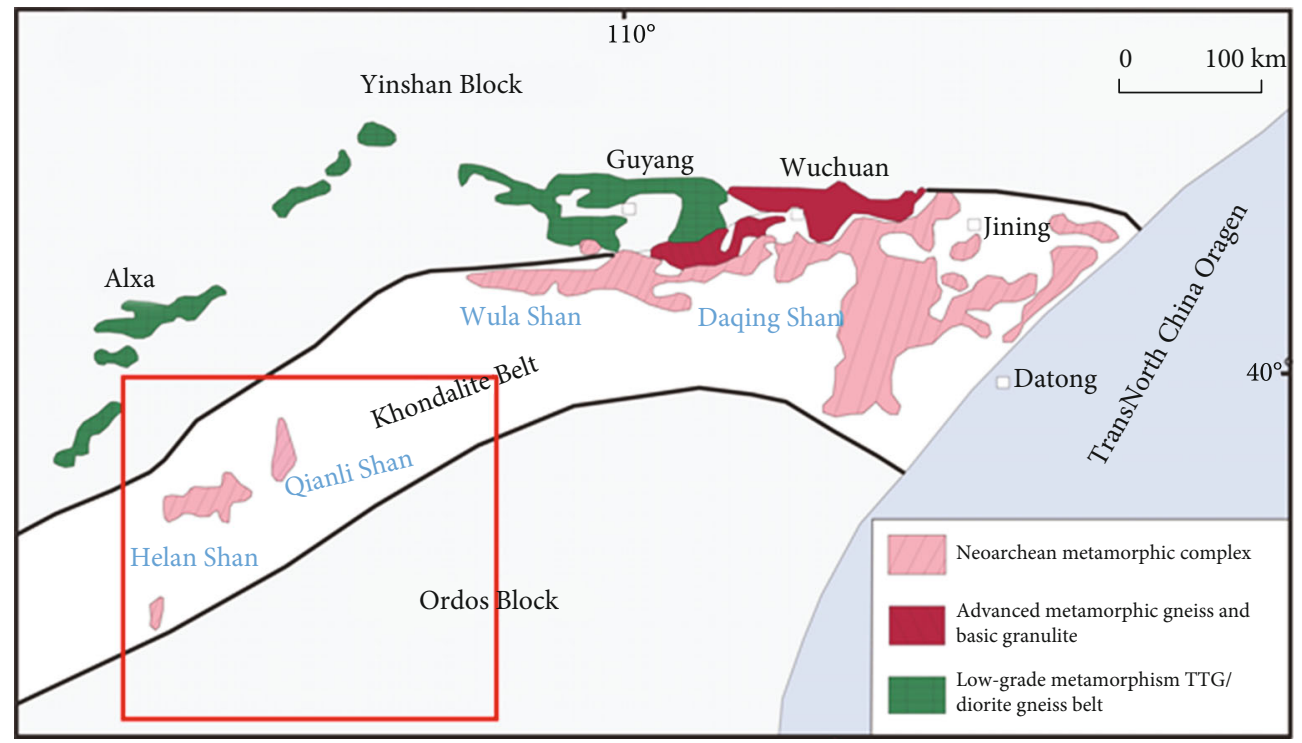

(a)

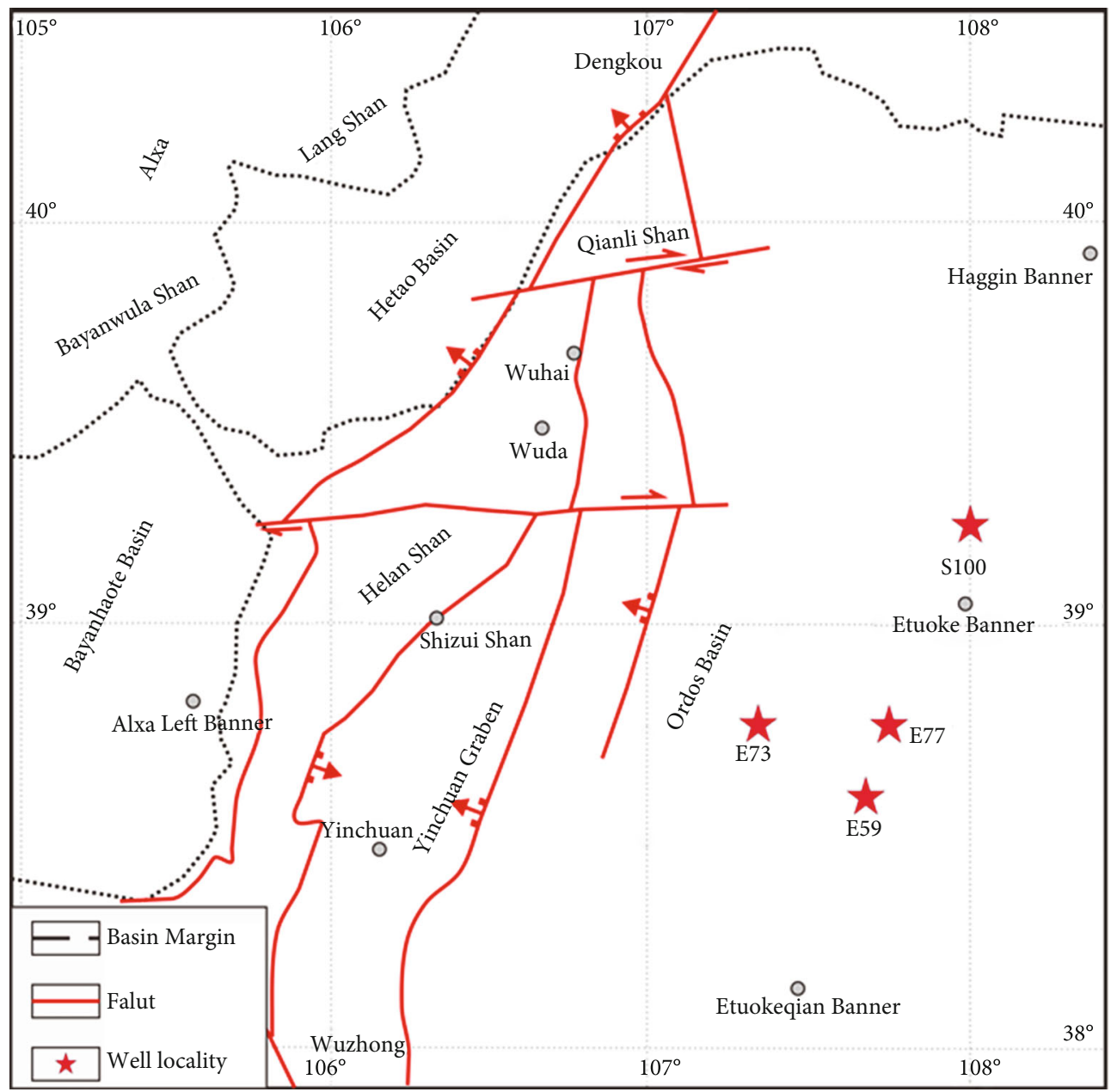

(b)

Figure 1: Geological map of the study area. (a) Distribution map of the metamorphic basement in the northern Ordos Basin (modified after [1]). (b) Structural map of the northwestern Ordos Basin (modified after Li Meng et al., 2015). 
Table 1: Sampling formation of Upper Paleozoic clastic zircon in the northwestern Ordos Basin.

\begin{tabular}{lccc}
\hline Well ID & Formation & Depth $(\mathrm{m})$ & Lithology description \\
\hline S100 & Shanxi group & 3392.3 & Light gray gravel-bearing coarse sandstone \\
E59 & Shanxi group & 3688.6 & Gray white coarse sandstone \\
E73 & Shanxi group & 3892.0 & Gray coarse sandstone \\
E77 & Shanxi group & 3666.0 & Light gray medium sandstone \\
\hline
\end{tabular}

Formation, Lower Permian Taiyuan Formation, Shanxi Formation, Lower Shihezi Formation, Upper Permian Upper Shihezi Formation, and Shiqianfeng Formation. Regarding their provenance, previous studies were only in a single deposit qualitative analysis based on science ([2]; Wang Guoru, 2011), and the isotopic dating results of the source rock are relatively few.

\section{Sample Petrology}

This study used zircon LA-MC- ICPMS U-Pb dating analysis technology to analyze the sandstone samples from Well S100, Well E59, Well E73, and Well E77 in the Shanxi Formation in the Otuokeqi area of the northwestern Ordos Basin. The location of the wells is showed in Figure 1. Combining the outcrops and structural evolution characteristics of the surrounding terrane to determine the material source in the study area and accurately determine the age of the source rock of the sedimentary source of the Shanxi Formation. At the same time, invert the geological historical events in the northwest and surrounding areas of the Ordos Basin. The sandstone sample depth is shown in Table 1. The sample is basically quartz sandstone. The composition of the sample is about $85 \%$ of quartz and about $15 \%$ of cuttings and other minerals. The clastic particles are semiangular and subangular to subcircular, showing a poorer medium roundness. Coarse sandstone is the main particle size of the sandstone, followed by the sorted medium sandstone.

\section{Analytical Methods and Results}

3.1. Zircon $\mathrm{U}-\mathrm{Pb}$ Dating. The core samples used in the single well in this study weighed more than $1 \mathrm{~kg}$ which was crushed in the Laboratory of Langfang Regional Geological Survey Research Institute, Hebei Province. After that, the crushed samples were separated using heavy mineral as well as heavy liquid techniques and then picked under a binocular stereoscope. Subsequently, the representative samples were placed in epoxy resin, then ground and polished to about onethird of the original particle for the subsequent analyses. Cathodoluminescence (CL) microscopic images, LA-ICPMS zircon U-Pb chronology, and LA-MC-ICP-MS zircon Lu-Hf isotope analysis were carried out at the State Key Laboratory of Continental Dynamics, Department of Geology, Northwest University. The specific experimental conditions and methods can be seen at references ([3]; Liu Xiaoming et al., 2007).

3.2. Results. The detrital zircons samples from Well S100, Well E59, Well E73, and Well E77 in the Shanxi Formation in the study area have similar morphology which are presented in Figure 2. The cathodoluminescence (CL) photos show that the detrital zircons are mostly gray and light brown with the semiautomatic short column-columnar or round shape. The zircon particles are well preserved and have a clear core-edge structure. Most of the cores have clear oscillatory zoning, and the $\mathrm{Th} / \mathrm{U}$ ratio is over 0.4 suggesting a typical magmatic origin. Some zircon has a nonoscillatory zoning structure which is indicating the metamorphism origin ([4]; Wu Yuanbao and Zheng Yongfei, 2004).

In this study, the LA-ACP-MS U-Pb age test was performed on the detrital zircon particles of sandstone samples from Well S100, Well E59, Well E73, and Well E77 in the Shanxi Formation. Use Isoplot software to process the concordant data and draw the zircon U-Pb concordia diagrams and the age distribution histogram. When the age value is greater than $1000 \mathrm{Ma}$, the $\mathrm{U}-\mathrm{Pb}$ isotope age is taken as the age value corresponding to ${ }^{207} \mathrm{~Pb} /{ }^{206} \mathrm{~Pb}$; when the age value is less than $1000 \mathrm{Ma}$, the $\mathrm{U}-\mathrm{Pb}$ age is taken as the age value corresponding to ${ }^{206} \mathrm{~Pb} /{ }^{238} \mathrm{U}$, and $\mathrm{U}-\mathrm{Pb}$ concordia diagrams and histogram can be seen at Figure 3.

A total of 130 detrital zircons were obtained from the samples from Well S100. The age of 42 zircons is discordant, and the rest of zircons grains are selected for the final interpretation. Among them, three grains yielded age of $(2530.3 \pm 26) \mathrm{Ma},(2511.1 \pm 19) \mathrm{Ma}$, and $(2501.8 \pm 20) \mathrm{Ma}$, which belongs to Neoarchean zircons. About $85.2 \%$ of those are in the age group 1682.7-2487.2 Ma with the main peak of $1837 \mathrm{Ma}, 2093 \mathrm{Ma}$, and $2370 \mathrm{Ma}$, which can be determined as Paleoproterozoic detrital zircons. One younger zircon age is $(424.1 \pm 2) \mathrm{Ma}$ which is Middle Silurian. $8 \%$ fall within $300.9-351.5 \mathrm{Ma}$ with the average ${ }^{206} \mathrm{~Pb} /{ }^{238} \mathrm{~Pb}$ age of 318.1 Ma belong to the Carboniferous. The rest 2 zircon grains are the Early Middle Permian yielding the age of $(296.1 \pm 2) \mathrm{Ma}$ and $(286.7 \pm 2) \mathrm{Ma}$.

In total, 114 single detrital zircon grains were analyzed from Well E59. 102 zircons were selected for the final interpretation. 4 zircon grains belong to Neoarchean with an average ${ }^{207} \mathrm{~Pb} /{ }^{206} \mathrm{~Pb}$ age of $2533.8 \mathrm{Ma}$. About $58.8 \%$ fall into $1706.9-2490.3 \mathrm{Ma}$ with main peaks of $1854 \mathrm{Ma}$ and $2436 \mathrm{Ma}$ that are Paleoproterozoic grains. One zircon grain yielded $(1314.4 \pm 50) \mathrm{Ma}$ indicating Mesoproterozoic grain. One zircon age of ( $474.8 \pm 6)$ Ma represents Early Ordovician grain. Six zircon grains have the average ${ }^{206} \mathrm{U} /{ }^{238} \mathrm{~Pb}$ age of $425.3 \mathrm{Ma}$ which belongs to Silurian. 2 Devonian zircon grains shown the age of $(395.6 \pm 5) \mathrm{Ma}$ and $(355.7 \pm 5) \mathrm{Ma}$. About $18.6 \%$ fall within the age group $300.7-348.3 \mathrm{Ma}$ with the average age ${ }^{206} \mathrm{~Pb} /{ }^{238} \mathrm{U}$ of $320.5 \mathrm{Ma}$, belonging to the Carboniferous. 9 younger grains yield the average ${ }^{206} \mathrm{~Pb} /{ }^{238} \mathrm{U}$ age of 285.0 Ma that belong to the Early Middle Permian. 
Figure 2: Cathodoluminescence image of detrital zircon samples from the Shanxi Formation in the Etuokeqi area.

Well E 73 had acquired 102 detrital zircon ages, 90 of which are concordant. Among them, the average ${ }^{207} \mathrm{~Pb} /{ }^{206} \mathrm{~Pb}$ age of 6 Neoarchean zircon grains is $2595 \mathrm{Ma}$. 56 zircon grains which accounting for about $62.2 \%$ range in age from 1698.5 to $2481.6 \mathrm{Ma}$ with peaks at $1839 \mathrm{Ma}$ and $2445 \mathrm{Ma} .6$ Mesoproterozoic zircon grains have an average age of 1365.2 Ma. The remaining 22 Paleozoic zircon ages range from 297.1 to $476.7 \mathrm{Ma}$ with an average age of $348.2 \mathrm{Ma}$ that are dominated by the Carboniferous-Early Middle Permian, accounting for $18.9 \%$ of the total.

Altogether, 102 single detrital zircon grains of Well E 77 were analyzed, and 95 grains were chosen for the final interpretation. The average age of 5 Neoarchean zircon grains yielded the average ${ }^{207} \mathrm{~Pb} /{ }^{206} \mathrm{~Pb}$ age of $2546.9 \mathrm{Ma}$. 35 Paleoproterozoic zircon grain ages range from 1619.2 to 2493.5 Ma, with peaks at $1865 \mathrm{Ma}$ and $2422 \mathrm{Ma}$. 2 Mesoproterozoic zircon grains yielded concordia age at (1339.6 \pm 39$)$ $\mathrm{Ma}$ and $(1165.7 \pm 43) \mathrm{Ma}$, respectively. 6 Ordovician zircon grains yielded an average ${ }^{206} \mathrm{~Pb} /{ }^{238} \mathrm{U}$ age at $455.6 \mathrm{Ma}$ as well as 5 Silurian grain average ages are $428.4 \mathrm{Ma}$. The average age of 9 Devonian zircon grains is $401.1 \mathrm{Ma}$. The age of 31 Carboniferous-Early Middle Permian zircon grains ranges from 340.7 to $377.6 \mathrm{Ma}$ with the average ${ }^{206} \mathrm{~Pb} /{ }^{238} \mathrm{U}$ age of 309.9 Ma. Also, one Paleoarchean metamorphic zircon (Figure 2 E77-018) with the age of $(3398.8 \pm 31) \mathrm{Ma}$ and one Neoproterozoic metamorphic zircon (Figure 2 E77015) with the age of $(949.1 \pm 9)$ Ma was found in this sample which is recording the important geological events.

To sum up, the zircon age spectrum of the sandstone samples in the study area is consistent. Four principal age peak ranges are recognized, 470 400 Ma, 360 260 Ma, $2100 \sim 1600 \mathrm{Ma}$, and 2500 2300 Ma. The age is dominated by Paleoproterozoic and Carboniferous-Early Middle Perm- ian and followed by Neoarchean, Mesoproterozoic and Early Paleozoic detrital zircons.

3.3. Zircon Hf Isotopic Characteristics. In this paper, in situ Lu-Hf isotope analyses were carried out on selected 38 young zircon grains with concordance ages of Well E 59 and Well S100 to calculate $\varepsilon \operatorname{Hf}(t)$ values and two-stage depleted mantle model ages $\left(T_{\mathrm{DM} 2}\right)$. As illustrated in Table 2, except for the sample E 59-126 zircon whose ${ }^{176} \mathrm{Lu} /{ }^{177} \mathrm{Hf}$ ratio is greater than 0.002 , the ${ }^{176} \mathrm{Lu} /{ }^{177} \mathrm{Hf}$ ratio of other zircons is all less than 0.002 with the average value of 0.0009 , indicating a low level of radioactive $\mathrm{Hf}$ accumulation after the zircons were formed. Given that the $\mathrm{Lu} / \mathrm{Hf}$ ratio (f Lu/Hf $=-0.97$ ) of zircon grains is significantly smaller than that of the silicoaluminous continental crust ( $\mathrm{Lu} / \mathrm{Hf}=-0.72$ ), the $\varepsilon \mathrm{Hf}(t$ ) values of all zircons fall below the depleted mantle evolution curve which can be seen in Figure 4; so, the two-stage model age $\left(T_{\mathrm{DM} 2}\right)$ more truly reflects the time when the source material was extracted from the depleted mantle ([5]; Wu Fuyuan et al., 2007, p. Wu Chunrong et al., 2007). The Hf two-stage model age distribution in the zircon samples measured this time is widely ranged from $2491 \mathrm{Ma}$ to $1175 \mathrm{Ma}$ but mainly distributed in 2300-1500 Ma.

Well E 59 has obtained $27 \mathrm{Hf}$ isotopic data. The $\varepsilon \mathrm{Hf}(t)$ values vary widely from -18.36 to 4.33 with an average of -7.72. The ratio of ${ }^{176} \mathrm{Hf} /{ }^{177} \mathrm{Hf}$ is distributed between 0.282060 and 0.282634 , and the $T_{\mathrm{DM} 2}$ ranges from $2491 \mathrm{Ma}$ tol175Ma with an average of $1839 \mathrm{Ma}$. The $\varepsilon \mathrm{Hf}(t)$ value of 3 zircons is positive that ranges from 1.28 to 4.33 with an average of 2.54 . The $T_{\mathrm{DM} 1}$ is $875 \mathrm{Ma}, 882 \mathrm{Ma}$, and $914 \mathrm{Ma}$, respectively, with an average of $890 \mathrm{Ma}$. The corresponding $T_{\mathrm{DM} 2}$ is $1206 \mathrm{Ma}, 1234 \mathrm{Ma}$, and $1175 \mathrm{Ma}$, respectively, with an average of $1205 \mathrm{Ma}$, indicating the sediment sources from 

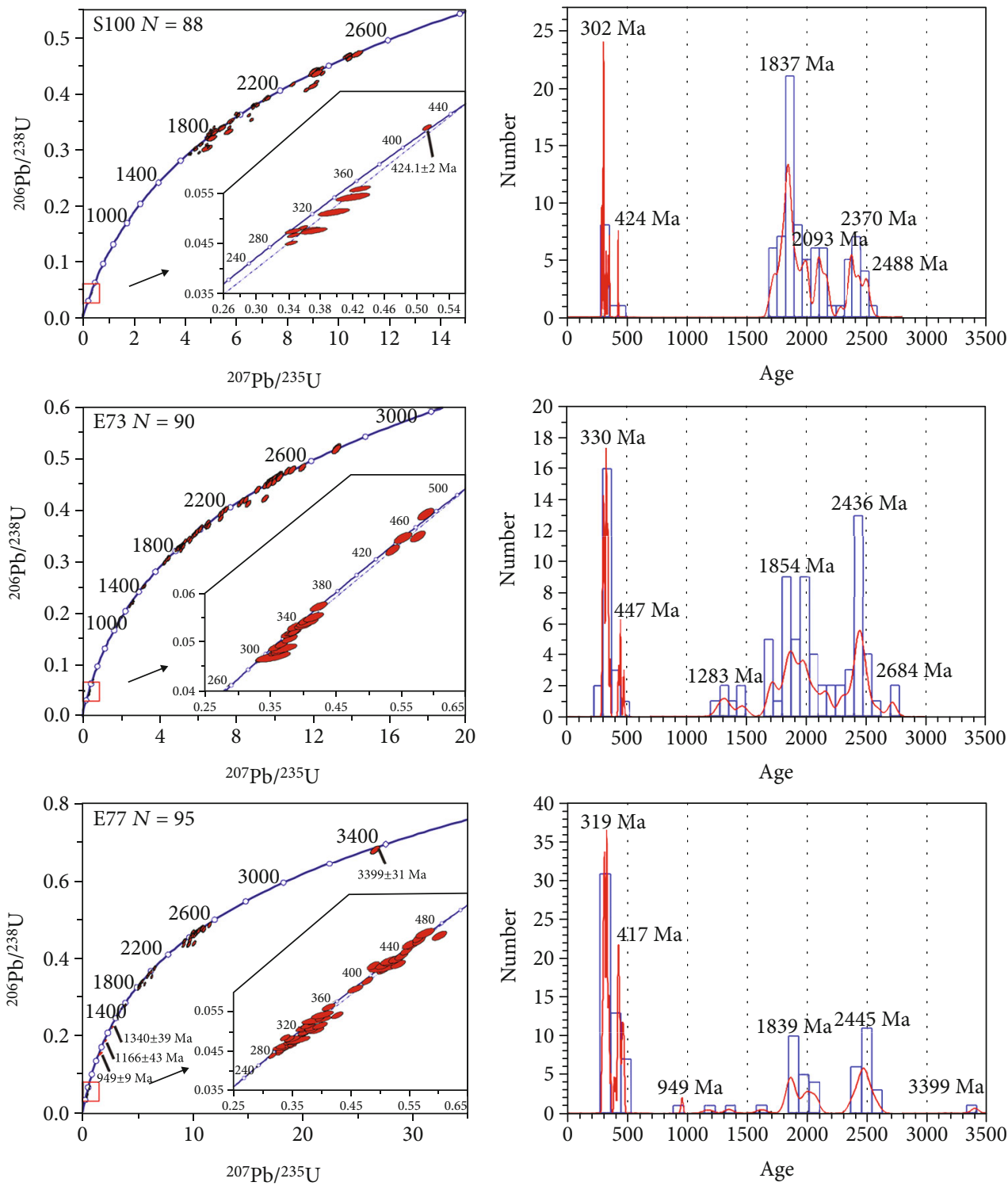

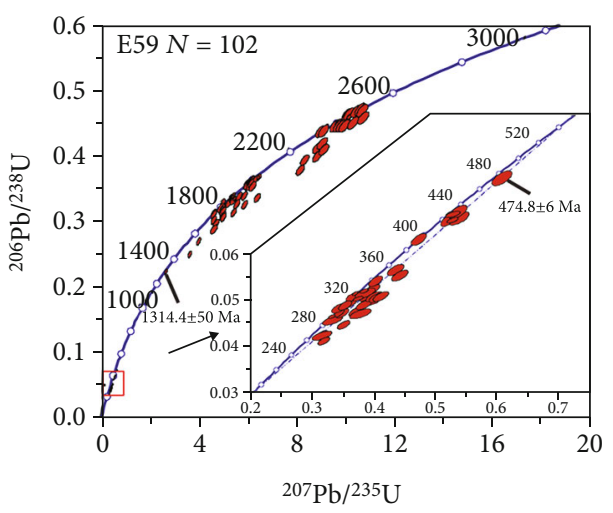

(a)

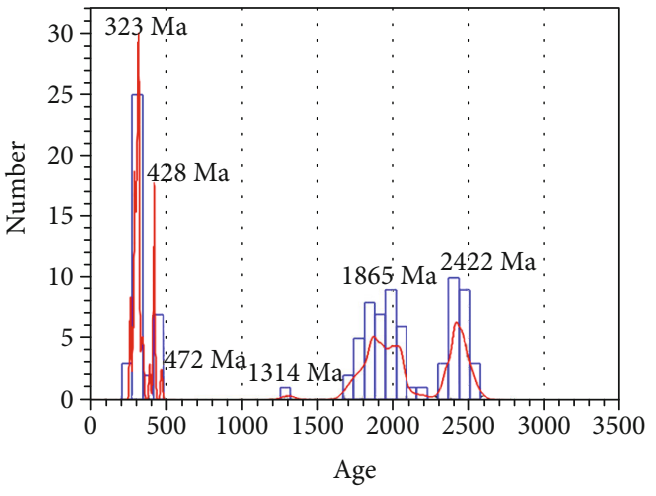

(b)

Figure 3: (a) shows the U-Pb concordia plots of concordant detrital zircons from the Shanxi Formation in the Otuokeqi area. (b) shows the detrital zircon $\mathrm{U}-\mathrm{Pb}$ age $(\mathrm{Ma})$ spectra including probability density curve and histograms. 
TABLE 2: Hf isotope analyses of zircons for the samples of the study area.

\begin{tabular}{|c|c|c|c|c|c|c|c|c|c|c|c|}
\hline $\begin{array}{l}\text { Sample } \\
\text { name }\end{array}$ & $\begin{array}{l}\text { Age } \\
(\mathrm{Ma})\end{array}$ & ${ }^{76} \mathrm{Yb} /{ }^{177} \mathrm{Hf}$ & $1 \mathrm{~s}$ & ${ }^{76} \mathrm{Lu} /{ }^{177} \mathrm{Hf}$ & $1 \mathrm{~s}$ & ${ }^{176} \mathrm{Hf} /{ }^{177} \mathrm{Hf}$ & $1 \mathrm{~s}$ & $\varepsilon \mathrm{Hf}(t)$ & $\begin{array}{l}T_{\mathrm{DM} 1} \\
(\mathrm{Ma})\end{array}$ & $\begin{array}{l}T_{\mathrm{DM} 2} \\
(\mathrm{Ma})\end{array}$ & $f_{\mathrm{Lu} / \mathrm{Hf}}$ \\
\hline E59-022 & 70.3 & 0.021354 & 000214 & 0.000858 & 0.000008 & 0.282446 & 0.000020 & -5.76 & 1136.6 & 1660.2 & 4377 \\
\hline E59-023 & 269 & 0.013658 & 0.000018 & 0.000516 & 0.000001 & 0.282347 & .000023 & & 1263.3 & 878.8 & 9777 \\
\hline E59-027 & 2.9 & 0.027444 & 0.000201 & 0.000967 & 0.000007 & 0.282634 & 0.000026 & 2.02 & 874.6 & 1205.5 & 77723 \\
\hline E59-031 & 23 & 0.004245 & 000014 & 0.000150 & 0.000001 & 0.282486 & 000023 & -0.84 & 1059.9 & 464.0 & -0.9 \\
\hline 36 & 0.2 & 13 & 0080 & 01 & 0.000003 & 68 & 00023 & -10.73 & 375.9 & 19.4 & -0 . \\
\hline 37 & 0.7 & 61 & 86 & 60 & 16 & 51 & 00018 & & 1559.2 & 91.7 & 096 \\
\hline 38 & 1.2 & 60 & 57 & 10 & 05 & 73 & 00021 & & 5.3 & 8.1 & -0 . \\
\hline לתס לת & 9.5 & & 2 & 45 & 03 & & 19 & & & 4.7 & -0 \\
\hline 59-042 & 3.7 & & & & & & & & 881.9 & & \\
\hline 59-045 & 1.4 & 95 & & 93 & 0.000006 & & 000032 & & 1429.6 & 107.2 & \\
\hline 59-046 & 9.7 & & 0027 & 15 & 0.000001 & & 20 & & .9 & 3.0 & -0.9 \\
\hline E59-049 & 5.6 & & 00059 & 23 & 0.000002 & & 00021 & & 1444.8 & 2076.1 & -0.97 \\
\hline E59-050 & 0.6 & 0.020822 & 000032 & 0.000784 & 0.000001 & & 000018 & -7.92 & 1347.1 & 1909.9 & -0.97 \\
\hline E59-054 & 1.2 & 0.018511 & 0.000099 & 0.000694 & 0.000004 & 260 & 000018 & -8.83 & 1389.4 & 1975.2 & -0.97 \\
\hline E59-055 & 5.6 & 0.019686 & .000169 & 0.000828 & 0.000007 & 0.282422 & 0.000019 & -5.8 & 1168.4 & 690.9 & -0.9 \\
\hline E59-066 & 0.8 & 0.008624 & 000233 & 0.000368 & 0.000008 & 82224 & 0.000018 & & 1427.5 & 2107.0 & -0.5 \\
\hline E59-083 & 5.7 & 0.025528 & 000054 & 0.000935 & 0.000002 & 2164 & 0.000019 & & 1531.8 & 2238.6 & 1271 \\
\hline E59-085 & 309 & 0.019663 & 00069 & 17 & 0.000002 & 504 & 00019 & -2 & 1053.7 & 05.1 & -0 . \\
\hline E59-091 & 24.9 & 0.015784 & 00087 & 0.00 & 0.000003 & 56 & 00025 & -0 . & 975.2 & 75.7 & -0.5 \\
\hline E59-096 & 4.8 & 0.02 & 0284 & 80 & 10 & 09 & 0021 & & 913.9 & 75.0 & -0 \\
\hline E59-101 & 4.5 & 0.045 & 00163 & 26 & 0.000006 & 243 & 0.000022 & -11 & 1444.2 & 89.0 & -0 . \\
\hline E59-106 & 4.3 & 0.040962 & 00549 & 34 & 0020 & 369 & 00025 & -8 & 1266.9 & 26.5 & -0 . \\
\hline E59-113 & 8.3 & 0.023718 & 00133 & 49 & 0005 & 147 & 000019 & -12 & 1552.4 & 32.2 & -0.5 \\
\hline E59-118 & 428 & 0.007083 & 00020 & 43 & 0.000001 & 259 & 0.000023 & -8 & 1374.7 & 1971.7 & -0.9 \\
\hline E59-122 & 318 & 0.021532 & & & 0.000002 & & .000019 & & 1669.8 & 490.6 & \\
\hline E59-129 & 420.6 & & & & & & & & & & -0.98 \\
\hline E59-126 & & & & & & & & & & & -0.9 \\
\hline S100-003 & & & & & & & & & & & \\
\hline S100-042 & & & & & & & & & & & \\
\hline S100-058 & & & 0180 & & & & 22 & & & 4.0 & 096 \\
\hline S100-0 & 2.6 & & 0 . & & & & 0018 & -6.45 & 1199.2 & 7.9 & -0.96 \\
\hline S100-076 & 296.1 & & 0.000023 & 0. & 1 & 2431 & 0.000014 & & & 9.1 & 545 \\
\hline S100-095 & 323.6 & 0.050873 & 0.000062 & 0.001815 & 0.000003 & 32326 & 0.000021 & & 1337.0 & 1908.0 & -0.94 \\
\hline S100-097 & 301.2 & 0.018165 & 0.000025 & 0.000657 & 0.000001 & 0.282167 & 0.000015 & & 1517.5 & 2262.9 & -0.98020887 \\
\hline S100-099 & 302.6 & 0.044649 & 0.000115 & 0.001576 & 0.000004 & 0.282367 & 0.000019 & -7.99 & 1270.3 & 1825.4 & -0.95252991 \\
\hline S100-101 & 305 & & 0.000313 & 0.001244 & 0.000011 & & 0.000020 & & 1273.7 & 1843.2 & -0.962532319 \\
\hline S100-120 & 300.9 & 0.030852 & 0.000148 & 0.001117 & 0.000004 & 0.282475 & 0.000019 & -4.12 & 1103.3 & 1579.3 & -0.966364578 \\
\hline S100-123 & 24.1 & 0.015654 & 0.000042 & 0.000545 & 0.000002 & 0.282232 & 0.000016 & -9.94 & 1422.9 & 2039.9 & -0.9835740 \\
\hline
\end{tabular}

the Mesoproterozoic exist besides the reworking of the significantly older crust of the Paleoproterozoic.

11 Hf isotope data were obtained for the samples from Well S 100. The $\varepsilon \mathrm{Hf}(t)$ values are all negative, ranging from -14.94 to -4.12 , with an average of -8.07 . The ratio of ${ }^{176} \mathrm{Hf} /{ }^{177} \mathrm{Hf}$ is distributed from 0.282167 to 0.282475 . The $T_{\mathrm{DM} 2}$ is from 2263 to $1579 \mathrm{Ma}$ with an average of $1845 \mathrm{Ma}$, suggesting that the predominant source is the reworking of the ancient crust of Paleoproterozoic.
The calculation uses chondrite $\left({ }^{176} \mathrm{Hf} /{ }^{177} \mathrm{Hf}\right)_{\mathrm{CHUR}, 0}=$ 0.282772 , $\left({ }^{176} \mathrm{Lu} /{ }^{177} \mathrm{Hf}\right)_{\mathrm{CHUR}}=0.0332$ (Blichert Toft et al., 1997), current depleted mantle $\left({ }^{176} \mathrm{Hf} /{ }^{177} \mathrm{Hf}\right) \mathrm{DM}=0.28325$, $\left({ }^{176} \mathrm{Lu} /{ }^{177} \mathrm{Hf}\right) \mathrm{DM}=0.0384$ (Griffin et al., 2000), continental crust $\left({ }^{176} \mathrm{Hf} /{ }^{177} \mathrm{Hf}\right)$ average crust $=0.015$ (Rudnick RL et al., 2003), and ${ }^{176} \mathrm{Lu}$ decay constant $\lambda=1.865 \times 10^{-11} / \mathrm{a}$ (Schere et al., 2001), and $\varepsilon \operatorname{Hf}(t)$ is calculated using the surface age of a single particle zircon ${ }^{206} \mathrm{~Pb} /{ }^{238} \mathrm{~Pb}$. 


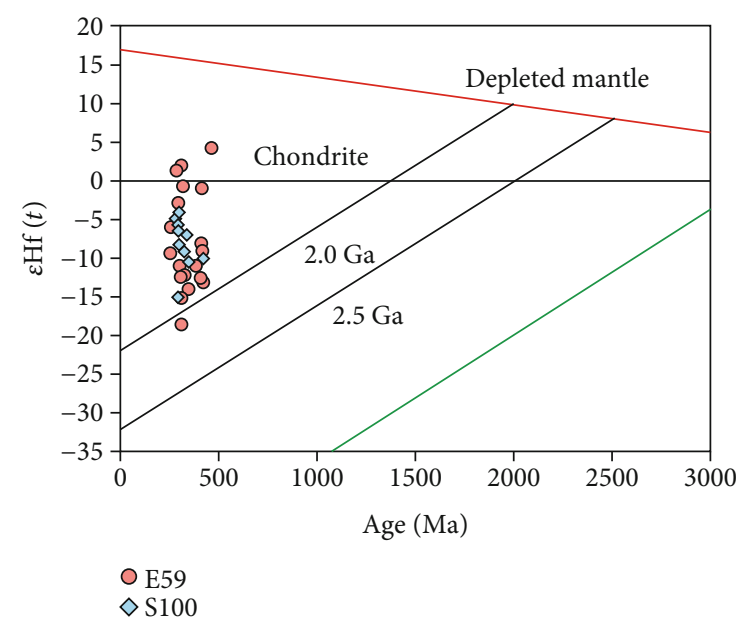

Figure 4: Plots of $\varepsilon \mathrm{Hf}(t)$ versus ${ }^{207} \mathrm{~Pb} /{ }^{206} \mathrm{~Pb}$ ages of all detrital zircons of the study area.

\section{Discussion}

4.1. Potential Provenance. The U-Pb age distribution of detrital zircons of the formation in a certain period in the sedimentary basin is similar if the provenances are the same. If the provenances are different and the ages of the sediments are significantly different, the similarity between the age spectra is poor. The comparison and comprehensive analysis of the ages of detrital zircons of the strata in the basin with the ages of the sediments exposed in the surrounding strata will provide an important basis for estimating the sediment source areas of the basin during the specific period, and it can also invert the important geological historical events of the periphery of the basin (Yan Yi et al., 2003).

4.1.1. Neoarchean-Palaeoproterozoic Potential Provenance Area $(2571 \sim 1683 \mathrm{Ma})$. The main part of detrital zircon (about 75\%) of the Neoarchean-Paleoproterozoic in E59 and S100 in the study area can be divided into two main peak ranges of $2100 \sim 1600 \mathrm{Ma}$ and $2500 \sim 2300 \mathrm{Ma}$, which are a good indication of the Precambrian Fuping and Luliang movements of the North China Craton. The North China Craton is one of the oldest cratons in the world. It has experienced the formation of continental nucleus and microcontinents of $\sim 3.0 \mathrm{Ga}$, crust growth of $2.7 \sim 2.9 \mathrm{Ga}$, cratonization events of $\sim 2.5 \mathrm{Ga}$, basement stretching-destruction event of 2. $3 \sim 1,9 \mathrm{Ga}$ and $1.8 \mathrm{Ga}$ regional basement uplift, nonorogenic magmatic activity, and rift-type volcanic-magmatic activity (Peng Peng and Zhai Mingguo, 2002, Zhai Mingguo, 2006, [6]; Zhai Mingguo and Peng Peng 2007; [6]) and other multistage complex tectonic evolution histories. The basement exposed in the Yinshan area in the northeastern part of the North China Craton is mainly the Neoarchean Wulashan Group and the Meso-New Proterozoic Zhaertai Group (Langshan Group), as well as a large number of neutralacid intrusions formed during the orogenic process of Central Asia since the Phanerozoic (Peng Runmin et al., 2015). The Kongzi rock belt of the North China Craton is mainly distributed from the east to west in the Jining-Wulashan-
Daqingshan-Qianlishan-Helanshan area. It is mainly composed of typical Khondalite series, TTG gneiss intercalated with mafic granulite, and syntectonic perilla granite or Stype granite (Zhao Guochun et al., 2002). In recent years, a large number of the chronological data have been obtained by dating zircons of different lithologies. The zircon U-Pb ages obtained from granulite and perilla granitic gneiss in the Wuchuan area of Inner Mongolia in the Yinshan block are $2507 \sim 2545 \mathrm{Ma}$ [7]. In the Guyang area of Inner Mongolia, $2562 \pm 14 \mathrm{Ma}, 2569 \pm 78 \mathrm{Ma}$ (Liu Li et al., 2012) amphibolite, and $2556 \mathrm{Ma}$ high-magnesium diorite, and $2520 \mathrm{Ma}$ amphibolite was discovered [8].

Daqingshan-Wulashan is the middle section of the Khoundzite belt [1]. Wu Changhua et al. (2006) measured the zircon surface ages of the potassium granites in the Wulashan-Jining area that are from 2494 to $2371 \mathrm{Ma}$. The age of the Early Paleoproterozoic granite in the Wulashan area is $2459 \pm 7 \mathrm{Ma}$, and the age of the perilla granite is $2430 \pm 8$ (Liu Jianhui et al., 2013). Xia et al. [9] revealed that the ages of detrital zircons in the Wulashan Kongziites are concentrated in $2.32 \sim 1.84 \mathrm{Ga}$. Ma et al. [10] and Wan et al. [11] obtained two metamorphic event ages of $\sim 1.95 \mathrm{Ga}$ and $\sim 1.85 \mathrm{Ga}$ in the Daqingshan area.

The Qianlishan-Helanshan area is located in the western part of the northern margin of the North China Craton and is part of the west extension of the Khondaite belt which is adjacent to the Alxa block by the fault ([1]; Yin et al., 2009, [1214]). The basement of the Helanshan area is the Helanshan metamorphic complex, which is composed of a large number of high-grade metamorphic aluminum-rich gneiss (Helanshan rock group), marble, and metamorphic deformed granite. It contains a certain amount of S-type granite. The age is dominated by Paleoproterozoic (Hu Neng Gao Gao, 1994; Zhou Xiwen and Geng Yuansheng, 2009; [12-14], Li Liming et al., 2014)) and also contains Archean rocks (Zhou Xiwen and Geng Yuansheng, 2009; [15]).

$\mathrm{Hu}$ and Yang [16] used the single-grain zircon evaporation method to obtain the biotite-monzonite bearing granulite in the Helan Mountain area. The ages are $2102 \sim 1902 \mathrm{Ma}$, and the ages of the fibrolite-garnetcordierite bearing gneisses are 1898 1853 Ma. The age of medium granite bearing garnet is $1975 \sim 1893 \mathrm{Ma}$. Dong et al. [15] used SHRIMP to obtain the average age of the residual zircons of the garnet-mica bearing monzonite gneiss of the Helanshan rock group as (1978 \pm 17$) \mathrm{Ma}$, and the age of the magmatic zircon of the gneissic granite in the Bayanwula-Helanshan area is $(2323 \pm 20) \mathrm{Ma}$, the ages of metamorphic zircons are $(1923 \pm 28)$ and $(1856 \pm 12)$ Dan et al. $[12,13]$ dated the porphyritic moyite invaded into the Khondalite series in the Zongbieli area and obtained the magma crystallization age of $(1947 \pm 6) \mathrm{Ma}$. The age of the biotite garnet gneiss is $(2056 \pm 18) \mathrm{Ma}$, and the crystallization age of the biotite granite in the Gunzhongkou area is $(1956 \pm 19)$ Ma. Yin et al. [14] measured the crystallization age of the S-type granite in the Helanshan Complex to be $(1840 \pm 19) \mathrm{Ma}$, and the age of the detrital zircon was 2.02 1.95 Ga. Geng et al. [17] used SHRIMP zircon U-Pb dating of the Helanshan metamorphic granite to determine that the biotite plagioclase gneiss was formed at $(2053 \pm 58)$ 
$\mathrm{Ma}$, and the garnet granite was formed at $(2047 \pm 42) \mathrm{Ma}$. The emplacement ages of porphyritic granite and gneissic diorite are $(1955 \pm 20) \mathrm{Ma}$ and $(1920 \pm 7) \mathrm{Ma}$, respectively. Zhou Xiwen and Geng Yuansheng (2009) used SHRIMP to obtain the overall age range of aluminum-rich gneisses (garnet cordierite potassium gneiss, garnet cordierite monzonite, garnet biotite plagiogneiss) in the Zongbieli area of the Helan Mountain between 2.1 and $2.0 \mathrm{Ga}$. Xiao et al. [18] measured the zircon ages of the garnet-sillimanite-biotite bearing monzonitic gneiss in the Zongbie Liyan formation in the northern section of the Helan Mountain which is mostly between 1.80 and $2.15 \mathrm{Ga}$. Li Zhenghui et al. (2013) measured the crystallization age of the S-type granite in the Helanshan area to be (1958 \pm 30$)$ Liming (2014) measured the age of the clastic magmatic zircon in the Zhaochigou section to be concentrated in $2.15 \sim 1.99 \mathrm{Ga}$, and the ages of metamorphic zircons are $(1961 \pm 46) \mathrm{Ma},(1951 \pm 42) \mathrm{Ma}$, and $(1869 \pm 45) \mathrm{Ma}$; moreover, the weighted average age of the biotite monzonitic granite in the Zhaochigou terrace is $(1958 \pm 41)$ Ma. Liu et al. [19] measured the LA-ICP-MS zircon U-Pb age of the porphyritic granite in the Helan Mountain area as (1922 \pm 31$)$ Zhirong et al. (2016) used LA-ICP-MS zircon U-Pb dating to obtain the age of the diabase dykes that intruded into the Helanshan rock group and the Paleoproterozoic granite in the northern section of the Helan Mountain as $(1853 \pm 82)$ $\mathrm{Ma}$ and $(1879 \pm 80) \mathrm{Ma}$. The age of the upper node of zircon in the Zongbieli diabase is $1993 \pm 87 \mathrm{Ma}$ (Wang Zhining, 2018). In summary, it can be seen that the depositional age of the protoliths of the Helanshan complex is around 2.02 billion years. Two sets of metamorphic ages of $\sim 1.95$ billion years and 1.87 billion years were recorded at the same time, which are consistent with the emplacement age of S-type granites in this area (Zhou Xiwen and Geng Yuansheng, 2009; [12-14], Li Zhenghui et al. 2013), providing corresponding sediment sources for the study area.

The base of the Qianlishan area is the Qianlishan complex, which is mainly composed of granulite facies highgrade regional metamorphic rock series (Qianlishan rock group) and a small amount of S-type granite. Yin et al. (2009) obtained the $(1875 \pm 19)$ Ma crystallization age from the S-type granite in Qianlishan, the sedimentary age of the clastic zircon original rock is slightly later than 2 billion years ago, and the metamorphic age is 195 million years ago. Darby and Gehrels' [20] Detrital zircon dating of Neoproterozoic to Ordovician sedimentary rocks in the Qianlishan area, there is a major age peak of 2.06-2.0 Ga.

The Alxa block is located in the northwestern part of the study area. It has long been considered to be the west extension of the Yinshan block of the North China Craton which collided with the Ordos block at $\sim 1.95 \mathrm{Ga}$ to form the western block of the North China Craton [1]. In recent years, with the development of more research work, multiple periods of tectonic thermal events have been identified in the Alxa area, with a complex evolutionary history (Li Junjian, 2006; [21, 22]; Li Jinyi, etc., 2012; [23]). The Early Precambrian basement of the Alxa block is mainly exposed in the Alxa Left Banner area in the east of the block. $t$ consists of the Neoarchean Diebuge complex (rock group), the Paleoproterozoic Bayanwulashan complex (rock group), the Paleo-
Mesoproterozoic Alxa complex (rock group), and the Boluositanmiao and Neoproterozoic Bijigetai two Plutonic gneisses. (Shen Qihan et al., 2005; [21, 24, 25]). The western basement of the block mainly exposes the Beidashan Complex in Alxa Right Banner [26] and the Longshoushan Complex on the north side of the Hexi Corridor [27, 28]. In recent years, a large number of early Cambrian metamorphic basement ages have been obtained in the East Alashan block through zircon dating. The zircon ages of the diabetic hornblende plagioclase gneisses of 3570-2750 Ma were obtained from the Dibsge complex. At the same time, two metamorphic ages of Late Neoarchean $(2.69 \sim 2.5 \mathrm{Ga})$ and Late Paleoproterozoic $(1.9 \sim 2.0 \mathrm{Ga})$ were obtained [25]. The $\mathrm{Rb}-\mathrm{Sr}$ isochron age of the amphibolite is $3219 \mathrm{Ma}$, and the Sm-Nd whole-rock isochron age is $3018 \pm 49 \mathrm{Ma}$ whose age belongs to the Middle Archean (Li Junjian, 2006). The metamorphic age of the diabolic gneiss is $1926 \pm 23 \mathrm{Ma}$, the metamorphic age of felsic gneiss is $1802 \pm 12 \mathrm{Ma}$, and the magma age of granodiorite gneiss is $1970 \pm 8 \mathrm{Ma}$ [21]. Dan et al. [12] dated the moyite intrusive age from $1981 \pm 10 \sim 1966 \pm 7 \mathrm{Ma}$ and obtained two metamorphic ages of $1898 \pm 17 \mathrm{Ma}$ and 1795 $\pm 8 \mathrm{Ma}$. The age of the granodiorite gneiss in the Bayanwula Mountain complex is $2082 \pm 22 \mathrm{Ma}$ (Li Junjian et al., 2004). The magmatic crystallization age of the biotite hornblende gneiss is $2271 \pm 8 \mathrm{Ma}$ and $2264 \pm 3 \mathrm{Ma}$ (Shen Qihan et al., 2005). Sm-Nd complete rock isochron age of plagioclase amphibolite is 2005 1920 Ma (Li Junjian, 2006). The zircon ages of biotite hornblende gneiss and muscovite felsic schist are 2500-2264 Ma which also have metamorphic age of Late Paleoproterozoic [25]. The magma crystallization age of the gneissic granite is $2323 \pm 20 \mathrm{Ma}$ and also acquired two metamorphic ages of $1923 \pm 28 \mathrm{Ma}$ and $1856 \pm 12 \mathrm{Ma}$ [15]. The magma crystallization age of orthogneiss is $2344 \pm 12 \sim$ $2303 \pm 5 \mathrm{Ma}$, the two metamorphic ages are $\sim 1.9 \mathrm{Ga}$ and $1.8 \mathrm{Ga}$, respectively, and the magma age of the granite dike is $1895 \pm 28[12,13]$. The magma crystallization ages of orthogneisses are $2301 \pm 20 \sim 2232 \pm 18 \mathrm{Ma}$, and their metamorphic ages are $\sim 1.91 \mathrm{Ga}$ and $\sim 1.85 \mathrm{Ga}$, respectively [29]. The diagenetic ages of the intrusive rocks in the Borostamiao complex are $1839 \pm 18 \mathrm{Ma}$ and $1818 \pm 19 \mathrm{Ma}$ (Shen Qihan et al., 2005), and the granite emplacement ages of the intrusive rocks are $1826 \pm 13 \mathrm{Ma}$ in the Qinggeltu biotite gneiss (Zhou Hongying et al., 2007). The age of amphibolite in the Longshoushan Group in the West Alxa Block is 2034 $\pm 16 \mathrm{Ma}$ [28]. the age of granitic gneiss is $1914 \pm 9 \mathrm{Ma}$ (Xiu Qunye et al., 2002), while the age of the trondhjemite is $2015 \pm 16 \mathrm{Ma}$ (Xiu Qunye et al., 2004). The ages of the detrital zircons in the paragneisses are mainly concentrated between 2.16 and $2.01 \mathrm{Ga}$, and the magma crystallization ages of the granite gneiss are $\sim 2.33 \mathrm{Ga}, \sim 2.17 \mathrm{Ga}$, and $2.04 \mathrm{Ga}$, respectively. Both the diorite gneisses and granodiorite gneisses with TTG characteristics in the Beidashan complex have the magma crystallization ages of 2.55 to $2.51 \mathrm{Ga}$ [26]. The Alxa block has experienced 2.7 3.0Ga continental crust growth, $2.5 \mathrm{Ga}$ TTG magmatic-metamorphic event, $2.0 \sim 2.3 \mathrm{Ga}$ magma event, and the two important metamorphic events of $1.9 \sim 1.95 \mathrm{Ga}$ and $1.80 \sim 1.85 \mathrm{Ga}$, which have strong consistency with the zircon age distribution of Shanxi Formation in the study area. 
The Langshan structural belt is located at the junction of the northern margin of North China and the southern margin of the Central Asian Orogenic Belt. The longterm multistage strong magmatism had complex and diverse rock types and well-exposed bedrocks. It is an important structure-magma evolution place for the study area. Sun et al. (2013) used dating techniques to conduct isotope chronological research on the metamorphic intrusions and zircons in the Baoyintu group quartzite and obtained the metamorphic intrusive gneissic monzonitic granite in the Baoyintu block. The SHRIMP zircon $\mathrm{U}-\mathrm{Pb}$ age is $1672 \pm 10 \mathrm{Ma}$, and the detrital zircon LA-ICP-MS zircon $\mathrm{U}-\mathrm{Pb}$ age range of the Baoyintu group quartzite is 2896 1426 Ma. Liu et al. [30] obtained that the detrital zircons of the Langshan Group have peak ages of $2.51 \sim 2.48 \mathrm{Ga}$ and $1.89 \sim 1.81 \mathrm{Ga}$ in the Late NeoarcheanPalaeoproterozoic and proved that there is $2.38 \sim 2.33 \mathrm{Ga}$ minor peak interval. Bao et al. (2019) measured the zircon age of the mica quartz schist in the northern Langshan area to be $2650-1187 \mathrm{Ma}$ which the main peaks of $1800 \mathrm{Ma}$, $1600 \mathrm{Ma}$, and $1200 \mathrm{Ma}$. The detrital zircons in the sandy mudstone in the southern part of Langshan can be divided into the age ranges of $2701 \sim 2413 \mathrm{Ma}$ and $1994 \sim 1809 \mathrm{Ma}$ with the peak ages of $2400 \mathrm{Ma}$ and $1950 \mathrm{Ma}$. The detrital zircon ages in the glutenite are divided into two age ranges of 2580 to $2427 \mathrm{Ma}$ and 2009 to $1683 \mathrm{Ma}$ whose peak ages are $2500 \mathrm{Ma}$ and $1900 \mathrm{Ma}$.

Based on the above analysis, it can be seen that the Guyang, Wuchuan, Langshan, and Alxa areas of the Yinshan block of the North China Craton have Neoarchean zircons that are similar in age to the study area. The main body of the Neoarchean zircon obtained by the research may be derived from the ancient TTG gneiss and basic granulite in the Yinshan block. The ages of a large number of zircons in the Daqingshan-Wulashan-Qianlishan-Helanshan area of the Kongzi rock belt are concentrated in $2.3 \sim 1.8 \mathrm{Ga}$, and there are two metamorphic event ages of $\sim 1.95 \mathrm{Ga}$ and $\sim 1.85 \mathrm{Ga}$ exist, indicating that the Paleoproterozoic gneiss and granite in the Kongzi rock belt can provide the main source material of Paleoproterozoic for the study area. At the same time, there are also Paleoproterozoic zircons in Langshan and Alxa areas, showing that they may also participate in supplying Paleoproterozoic zircon provenance in the study area which is showed in Figure 5. This is consistent with the previous conclusions drawn by methods of sedimentary debris, heavy mineral, and lithofacies paleogeographic distribution patterns in the study area [2].

As can be seen in Figure 2, a Paleoarchean metamorphic zircon with an age of $(3398.8 \pm 31) \mathrm{Ma}$ was found in the detrital zircon of Well E 77 in this study (E 77-018). The $\mathrm{U}-\mathrm{Pb}$ age of $(3690 \pm 35) \mathrm{Ma}$ was obtained from the detrital zircons in the Wushenqi area on the northern margin of the Ordos Basin [31]. Geng et al. [25] measured the U-Pb age of the zircon core of the Diabushige Group of the Diabushige Group in Alxa area to be $(3570 \pm 7)$ Ma. Therefore, there may be an ancient basement for more than 3 billion years old in the western of the North China Craton. The exposed basement has disappeared due to long-term weathering and erosion. However, these ancient materials are well preserved in the sediments of the basin, which can provide more comprehensive information for the tectonic evolution of the North China Craton $[5,11]$.

4.1.2. Probable Provenance Area in the Proterozoic (1492.8 949.1 Ma). In this study, nine Mesoproterozoic detrital zircons were found in sandstone samples from Well E 59, Well E 73, and Well E 77, which are well concordant, with ages ranging from 1492.8 to $1165.7 \mathrm{Ma}$. Also, the samples from Well E 77 A detrital zircon with a U-Pb age of (949.1 \pm 9$)$ Ma were also found. The zircon ages discovered in the Mid-New Proterozoic period have a good correspondence with the orogeny of the Greenville period. In the eastern part of the Alxa block, Liu et al. [30] conducted a chronological study on the Kyanite-bearing garnet mica quartz schist of the Deerhetongte Formation in the Altanobao area and found that the age of detrital zircon ranges from 3306 to $1146 \mathrm{Ma}$, and it is characterized by the occurrence of a high-frequency zone of Mesoproterozoic zircon ages. The smallest group of detrital zircons is about $1123 \mathrm{Ma}$, which is a set of continental margin deposits from the Late Mesoproterozoic to the early Neoproterozoic. At the same time, there are Meso-Neoproterozoic strata in the Longshoushan area in the west of the Alxa block and the Nuoergong-Diebsge area in the east. Xiao et al. (2015) analyzed the quartzites in the Zuzong Maodao Formation of the Alxa Group and found that the age of the detrital zircons obtained is between $3132 \mathrm{Ma}$ and $1206 \mathrm{Ma}$. Yang et al. (2001) obtained the Sm$\mathrm{Nd}$ model ages of two volcanic rocks in the Zhula Zagamaodao Formation, which are $1293 \mathrm{Ma}$ and $1187 \mathrm{Ma}$, respectively. Geng Yuansheng and Zhou Xiwen (2010) obtained age results of $913 \pm 7 \mathrm{Ma}, 921 \pm 7 \mathrm{Ma}, 926 \pm 15 \mathrm{Ma}$, and 904 $\pm 7 \mathrm{Ma}$ in the eyeball-shaped granite gneiss samples of Alxa Right Banner while there are few reports of granite of different ages in the interior of North China Craton. Hu et al. [35] studied the detrital zircons of the metasedimentary rocks in the Langshan Group to obtain the minimum age peak of $1187 \sim 810 \mathrm{Ma}$ and defined the age as Neoproterozoic. Liu et al. [30] obtained the ages of the detrital zircons of the Langshan Group with the main peak of $2.51 \sim 2.48 \mathrm{Ga}$ and $1.89 \sim 1.81 \mathrm{Ga}$ in the Late Neoarchean-Palaeoproterozoic, as well as $2.38 \sim 2.33 \mathrm{Ga}$ minor peak interval. At the same time, the ages of the Neoproterozoic zircons of $1.16 \mathrm{Ga}$ and $0.80 \mathrm{Ga}$ are shown, and detrital zircons that are deposited at $1.65 \mathrm{Ga}$ and $1.37 \mathrm{Ga}$ are also found in the Alxa Group. In summary, it can be seen that the ages of the Mesoproterozoic detrital zircons obtained in this study are coherent with the ages of deformed granites and sedimentary rocks in the Alxa and Langshan areas; so, the Mesoproterozoic detrital zircons obtained this time should be from the Alxa block in the western part of the basin.

4.1.3. Probable Provenance Area of Paleozoic (475 262 Ma). In this study, the Paleozoic detrital zircons were distributed from the Early Ordovician to the Early Middle Permian with the dominate of the Carboniferous-Permian. Due to the closure of the Paleo-Asian Ocean, the Yinshan block in the northern North China Craton has experienced strong orogenic activities since the Paleozoic. During this period, 

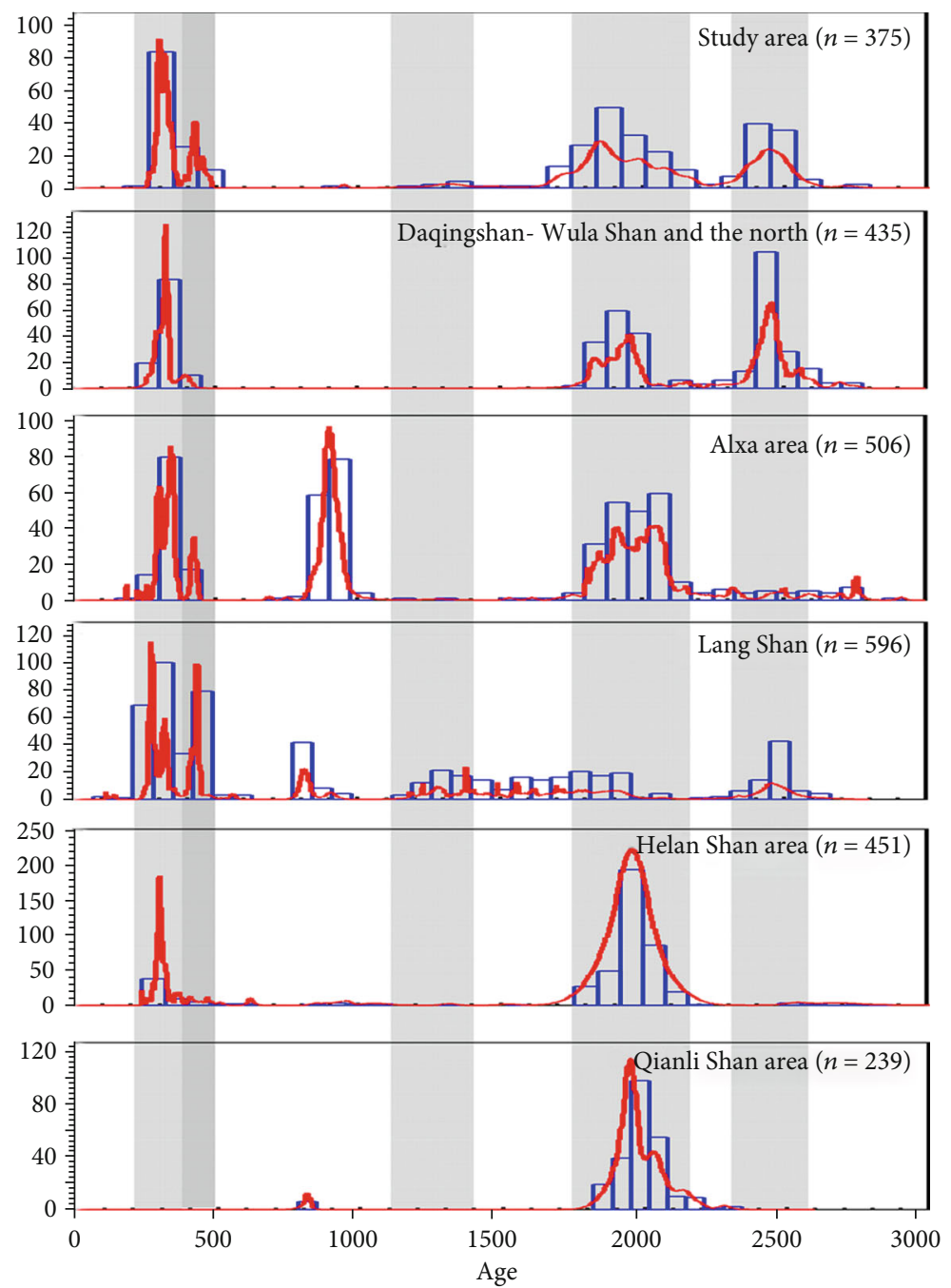

Figure 5: Comparison of zircon ages in the study area and the possible provenance area (Data quoted from YI et al., 2009, 2011; Peng Peng et al., 2018; Wang Zhining, 2018; Zhang Yun et al., 2019; [32]; Peng Runmin et al., 2010; Bao et al., 2019; [21]; Yang Qidi et al., 2014; [32-34]; Zhang Qiao et al., 2018; Wang Huichu et al., 2012; Wu Changhua et al., 2006; Liu Jianhui et al., 2013; [7]; Liu Li et al., 2012; [11]; Liu Chao et al., 2015).

multiple volcanic eruptions and large-scale intermediate-acid magma intrusions have occurred, and there are thousands of kilometers of magma belts (Zhang Shuanhong) Et al., 2010). Liu et al. (2015) measured the SHRIMP zircon U-Pb dating results of the granite, granodiorite, and diorite in the Guyang area of Inner Mongolia to be $330.8 \mathrm{Ma}, 324.7 \mathrm{Ma}$, and 329.2 Ma, respectively. The zircon age of the Gaojiacun horndiorite syenite in Guyang is between $417 \pm 10$ and $386 \pm 10$ Ma (Wang Huichu et al., 2012). The formation ages of the Dahuabei intrusions measured in the Wulashan area in southwestern Guyang are $353 \pm 7 \mathrm{Ma}$ (Miao Laicheng, 2001), $330 \pm 10 \mathrm{Ma}$ (Li Dapeng et al., 2009), and $328.3 \pm 1.5$ $\mathrm{Ma}$ [32]. The age of the volcanic rocks of the Tongshengmao Shuanmazhuang Formation in Daqingshan is $305 \mathrm{Ma}$ (Zhang Qiao et al., 2018). The SHRIMP U-Pb age of the zircon in the Kebu pluton in the Urad Middle Banner is 291 $\pm 4 \mathrm{Ma}$, and the TDM value is $2.38 \mathrm{Ga}$. The SHRIMP U-Pb age of the zircon in the Kebu granite in Wulate Central Banner is $291 \pm 4 \mathrm{Ma}$, and the TDM value is $2.38 \mathrm{Ga}$, which is formed by remelting ancient crustal materials [36]. Guyang and Daqingshan in the North China Craton are currently dominated by Late Paleozoic magmatic rocks. The provenance area of Ordovician-Silurian detrital zircons in this study cannot be Guyang and Daqingshan since the early Paleozoic Ordovician-Silurian granites have not been discovered in these areas.

Peng Peng et al. (2018) had measured the smallest age group of the Helanshan rock group to be $\sim 370 \mathrm{Ma}$, which approximately represents the emplacement age of the rock wall or is slightly larger than the emplacement age. The weighted average age of the magmatic zircon ${ }^{206} \mathrm{~Pb} /{ }^{238} \mathrm{U}$ in the Zongbieli diabase is about $304 \pm 3 \mathrm{Ma}$, and the Sm-Nd isotope analysis shows that the TDM is about $2.4 \mathrm{Ga}$ (Wang Zhining, 2018). Phanerozoic magmatic rocks dominate the outcrop area of the Alxa block that phanerozoic diorite, graniton, and granide are distributed in the Bayanwula Mountain, Beida Mountain, Longshou Mountain, Zongnai Mountain, Yamatu, and Nuoergong areas. Most of the zircon age data 


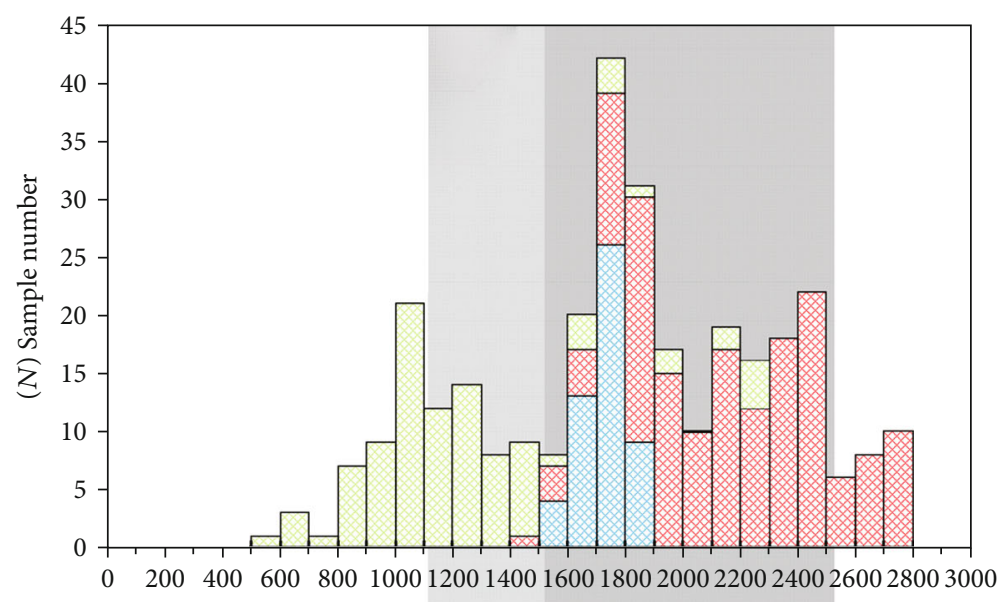

$\square$ Langshan area $(n=100)$

Alxa area $(n=160)$

$\square$ Daqingshan - Wulashan and the north area $(n=52)$

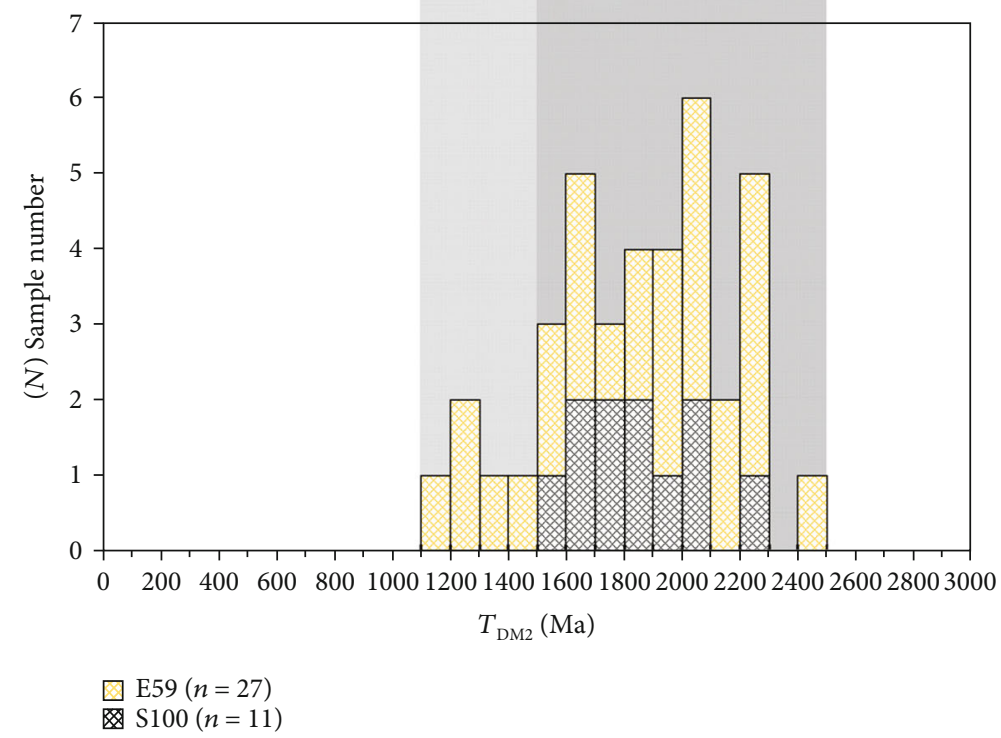

Figure 6: Two-stage model age comparison of Hf isotopes of zircons in Paleozoic age groups in the study area and probable provenance area (data quoted from Tian Jian et al., 2009; [32, 33]; Zhang Yun et al., 2019; Bao et al., 2019; [37]; Zhang Qiao et al., 2018).

of magmatic rocks are between 460 and $230 \mathrm{Ma}$, which can be roughly divided into three magmatic periods, Late Ordovician-Devonian, Carboniferous, and Permian-Early Triassic. Zircon Hf isotopic characteristics have indicated that the source rock is the recycle of ancient crustal materials (Li Junjian, 2006; Geng Yuansheng et al., 2012; [22]; Yang Qidi et al., 2014; [19, 30, 33, 37]). In recent years, researchers have done a lot of chronological and geochemical work on the Paleozoic intrusive rocks in the Langshan area, and a large amount of zircon age data had been obtained. Wang et al. [32] reported that the magmatic activity in the Langshan area experienced the Late Silurian ( 418 Ma), Carboniferous (328-304 Ma), Early Permian (294-272 Ma), Late Permian (260-254 Ma), and Middle Triassic (245-227 Ma) five stages. The weighted age of the Late Silurian two-mica granite is $418.0 \pm 2.3 \mathrm{Ma}$, and the zircon ages of the Early Carboniferous diorite and gabbro are $320.5 \pm 2.9 \mathrm{Ma}$ and $327.9 \pm 2.1 \mathrm{Ma}$, respectively.
The ages of the gabbro diorite are $320.2 \pm 1.9 \mathrm{Ma}$ and 272.6 $\pm 2.3 \mathrm{Ma}$, the ages of the Early Middle Permian syenite granite are $278.2 \pm 1.7 \mathrm{Ma}$, and the ages of the granodiorite are $273.2 \pm 1.6 \mathrm{Ma}$ and $259.5 \pm 1.4 \mathrm{Ma}$. The ${ }^{206} \mathrm{~Pb} /{ }^{238} \mathrm{U}$ weighted average age of the angled diorite gabbro on the west side of Langshan Mountain is $329.0 \pm 2.3 \mathrm{Ma}$, and the weighted average age of the granodiorite is $331.1 \pm 0.9$ $\mathrm{Ma} \sim 330.0 \pm 4.2 \mathrm{Ma}$ while the emplacement age is the Early Carboniferous (Tian Jian et al., 2018). The LA-ICP-MS zircon U-Pb age of the Early Devonian monzonitic granite shows that the weighted average age of ${ }^{206} \mathrm{~Pb} /{ }^{238} \mathrm{U}$ is 419.6 $\pm 4.5 \sim 416.0 \pm 2.0 \mathrm{Ma}$ (Tian Jian et al., 2019), the diorite in the northern part of Langshan. The age of body formation was Early Silurian $(437.7 \pm 2.2 \sim 435.8 \pm 2) \mathrm{Ma}$ (Zhang Yun et al., 2019). The results of zircon Lu-Hf isotope analysis showed that the two-stage model age $\left(T_{\mathrm{DM} 2}\right)$ was concentrated in 1361 690 Ma(Meso-Neoproterozoic). Bao et al. 
(2019) obtained 350-245 Ma and 431-254 Ma detrital zircon ages from sandy mudstone and glutenite in southern Langshan.

A lot of Lu-Hf isotope analysis on Paleozoic magmatic zircons had been done before. The comprehensive analysis result is demonstrated in Figure 6; it can be found that the $\mathrm{Hf}$ isotope characteristics of the Paleozoic magmatic zircons in Daqingshan-Wulashan in the North China Craton and the north area showed that the source rock is the recycle of ancient materials from the Neoarchean-Paleoproterozoic crust, while the magmatic source rock in the Paleozoic in the Alxa and Langshan areas contains the Mesoproterozoic crust and mantle material, which is similar to the Hf isotopic characteristics obtained from the zircons from Well E 59. Therefore, the Meso-Palaeozoic detrital zircons from the sandstones of the Shanxi Formation in the study area are likely to come from the igneous rock bodies formed in the Paleozoic in Langshan and Alxa areas.

4.2. Indicative Significance to the Greenville Orogen. At present, most researchers believe that the Rodinia supercontinent in the late Mesoproterozoic-Early Neoproterozoic was the combination of the extensive Greenwell and several continental blocks which separated at the early orogeny period of the same period from 1.3 to $1.0 \mathrm{Ga}$ after the collapse of the Colombian supercontinent [38]. However, there is still a lack of systematic research on whether there is a corresponding Greenville orogen in the northern margin of the North China block. The Meso-New Proterozoic detrital zircon and Paleozoic detrital zircon Hf isotopic two-stage model ages (1175 Ma, 1205.5 Ma, 1234.2 Ma) which was found in the sedimentary strata of the Ordos Basin can together reflect the existence of strong Greenwell Orogenic Movement in the provenance area. The large area of exposed Mesoproterozoic S-type granite of about $1000 \mathrm{Ma}$ in the western section of the Langshan Mountain in Inner Mongolia is undoubtedly an important sign of Late Mesoproterozoic orogeny in the northern margin of the North China Craton (Nie Fengjun et al., 1992) and mica quartz schist in this area. The peak zircon age of $1200 \mathrm{Ma}$ (Bao et al., 2019) represents the metamorphic and deformation event of orogeny. At the same time, the peak zircon age of the mica quartz schist in this area is $1200 \mathrm{Ma}$ (Bao et al., 2019), which represents the metamorphic deformation event of orogeny. Geng et al. [39], Geng Yuansheng, and Zhou Xiwen (2010) found synorogenic and strongly deformed Early Neoproterozoic magmatic event products in the western part of Alxa, in which the deformed granite has a zircon age of about $900 \mathrm{Ma}$, indicating that the Alxa area has undergone a strong transformation of orogeny in the Early Meso-New Proterozoic (Greenville period) and is different from the North China Craton. Peng et al. (2010) obtained magma ages of $817 \pm 5 \mathrm{Ma}$ and $805 \pm 5 \mathrm{Ma}$ from the SHRIMP U-Pb dating of acid volcanic rocks in the southwest of Langshan. Hu et al. [35] also obtained magma ages of $804 \pm 4 \mathrm{Ma}$, indicating that there may be a tectonic-magmathermal event in the Langshan area of Inner Mongolia that corresponds to the breakup of the Rodinia supercontinent (Peng Runmin et al., 2010). Combined with the Meso-New Proterozoic detrital zircons from the Alxa block found in the Ordos sediments in this study, it is reasonable to believe that the Alxa block has corresponding Greenwellian orogeny and participated in Rodinia (Rodini Convergence and fragmentation of subcontinents).

\section{Conclusion}

(1) The detrital zircons of the Shanxi Formation in the Otuokeqi area in the northwest of the Ordos Basin generally show four main peak age ranges of 470$400 \mathrm{Ma}, 360-260 \mathrm{Ma}, 2100-1600 \mathrm{Ma}$, and 2500$2300 \mathrm{Ma}$, respectively. The source rock is dominated by Paleoproterozoic according to the age of formation. The maximum age of detrital zircon is 3398.8 Ma, and the minimum age is $262 \mathrm{Ma}$

(2) Comparison of zircon ages with the surrounding strata and Hf isotopic characteristics shows that the provenance of the Shanxi Formation in the Late Paleozoic in the northwest of the Ordos Basin is complex. The source material is provided by several areas including the Guyang, Wuchuan, Langshan, and Alxa areas of the Yinshan block of the North China Craton and the Daqingshan-Wulashan-QianlishanHelanshan area of the Kongzi rock belt, with the Kongzi rock belt, Langshan, and Alxa predominate

(3) The Neoproterozoic clastic zircons (1492.8 949.1 Ma) found in the sedimentary strata in the northwestern part of the Ordos Basin reflect the existence of the Greenwellian orogenic event in the Alxa block during the geological history period related to the aggregation of the Rodinia supercontinent

\section{Data Availability}

Most of the data generated or analyzed during this study are included in this manuscript, and all of the data are available from the author on reasonable request.

\section{Conflicts of Interest}

The authors declare that they have no conflicts of interest.

\section{Acknowledgments}

This research was supported by the National Science and Technology Major Project of China(grant No. 2016ZX05050001). The research was also cosupported by the National Natural Science Foundation of China (grant No. 41421002).

\section{References}

[1] G. Zhao, M. Sun, S. A. Wilde, and L. Sanzhong, "Late Archean to Paleoproterozoic evolution of the North China Craton: key issues revisited," Precambrian Research, vol. 136, no. 2, pp. 177-202, 2005.

[2] W. T. Dou, M. C. Hou, and G. Y. Dong, "Source analysis of Shanxi formation and Xiashi box formation in northern ordos basin. Natural Gas Industry," vol. 29, no. 3, pp. 25-28, 2009. 
[3] H. Yuan, S. Gao, X. Liu, H. Li, D. Günther, and F. Wu, "Accurate $\mathrm{U}-\mathrm{Pb}$ age and trace element determinations of zircon by laser ablation-inductively coupled plasma-mass Spectrometry," Geostandards and Geoanalytical Research, vol. 28, no. 3, pp. 353-370, 2004.

[4] E. A. Belousova, W. L. Griffin, S. Y. O'Reilly, and N. Fisher, "Igneous zircon: trace element composition as an indicator of source rock type," Contributions to Mineralogy and Petrology, vol. 143, no. 5, pp. 602-622, 2002.

[5] J. Yang, S. Gao, C. Chen et al., "Episodic crustal growth of North China as revealed by U-Pb age and Hf isotopes of detrital zircons from modern rivers," Geochimica et Cosmochimica Acta, vol. 73, no. 9, pp. 2660-2673, 2009.

[6] M. G. Zhai, "Cratonization and the ancient North China continent: a summary and review," Science China Earth Sciences, vol. 54, no. 8, pp. 1110-1120, 2011.

[7] X. J. Dong, Z. Y. Xu, Z. H. Liu, and Q. Sha, "Zircon U-Pb chronology of Archaean high-grade metamorphic rocks in west Ulanbulang area, central Inner Mongoli," Chinese Science Earth Science, vol. 42, no. 7, pp. 1001-1010, 2012.

[8] P. Jian, Q. Zhang, D. Y. Liu, W. J. Jin, X. Q. Jia, and Q. Qian, "SHRIMP dating and geological significance of late Achaean high-mg diorite (sanukite) and hornblende-granite at Guyang of Inner Mongolia," Acta Petrologica Sinica, vol. 1, pp. 153159, 2005.

[9] X. Xia, M. Sun, G. Zhao et al., "U-Pb and Hf isotopic study of detrital zircons from the Wulashan khondalites: Constraints on the evolution of the Ordos Terrane, Western Block of the North China Craton," Earth and Planetary Science Letters, vol. 241, no. 3-4, pp. 581-593, 2006.

[10] M. Ma, Y. Wan, M. Santosh et al., "Decoding multiple tectonothermal events in zircons from single rock samples: SHRIMP zircon U-Pb data from the late Neoarchean rocks of Daqingshan, North China Craton," Gondwana Research, vol. 22, no. 3-4, pp. 810-827, 2012.

[11] Y. Wan, Z. Xu, C. Dong et al., "Episodic Paleoproterozoic $(\sim 2.45, \sim 1.95$ and $\sim 1.85 \mathrm{Ga})$ mafic magmatism and associated high temperature metamorphism in the Daqingshan area, North China Craton: SHRIMP zircon U-Pb dating and whole-rock geochemistry," Precambrian Research, vol. 224, pp. 71-93, 2013.

[12] W. Dan, X. H. Li, J. Guo, Y. Liu, and X. C. Wang, "Paleoproterozoic evolution of the eastern Alxa block, westernmost North China: evidence from in situ zircon $\mathrm{U}-\mathrm{Pb}$ dating and $\mathrm{Hf}-\mathrm{O}$ isotopes," Gondwana Research, vol. 21, no. 4, pp. 838-864, 2012.

[13] W. Dan, X. H. Li, J. Guo, Y. Liu, and X.-C. Wang, "Integrated in situ zircon $\mathrm{U}-\mathrm{Pb}$ age and $\mathrm{Hf}-\mathrm{O}$ isotopes for the Helanshan khondalites in North China Craton: Juvenile crustal materials deposited in active or passive continental margin?" Precambrian Research, vol. 222-223, pp. 143-158, 2012.

[14] C. Yin, G. Zhao, J. Guo et al., "U-Pb and Hf isotopic study of zircons of the Helanshan Complex: constrains on the evolution of the Khondalite Belt in the Western block of the North China Craton," Lithos, vol. 122, no. 1-2, pp. 25-38, 2011.

[15] C. Y. Dong, D. Y. Liu, J. J. Li et al., "New evidence for the formation age of the Kongzi belt in the western North China Craton: zircon SHRIMP dating and Hf isotopic composition in Bayanwula-Helanshan area," Chinese Science Bulletin, vol. 52, no. 16, pp. 1913-1922, 2007.

[16] N. G. Hu and J. X. Yang, "Discussion on the main metamorphic period of metamorphic complex in Helanshan group," Journal of Chang'an University, vol. 1, pp. 10-18, 1993.
[17] Y. S. Geng, X. W. Zhou, X. W. Wang, X. S. Wang, and L. D. Ren, "Late -Paleoproterozoic granite events and their geological significance in the Helanshan area, Inner Mongolia: evidence from geochronology," Acta Petrologica Sinica, vol. 25, no. 8, pp. 1830-1842, 2009.

[18] P. X. Xiao, W. F. You, C. R. Xie, P. Li, and S. M. Bai, "LA-ICP$\mathrm{MS} \mathrm{U}-\mathrm{Pb}$ detrital zircon geochronology of alumina-rich gneiss of the Helanshan complex-group in the northern segment of Helanshan Mountains and regional comparison," Geological Bulletin of China, vol. 30, no. 1, pp. 26-36, 2011.

[19] Q. Liu, G. Zhao, M. Sun et al., "Early Paleozoic subduction processes of the Paleo-Asian Ocean: insights from geochronology and geochemistry of Paleozoic plutons in the Alxa Terrane," Lithos, vol. 262, pp. 546-560, 2016.

[20] B. J. Darby and G. Gehrels, "Detrital zircon reference for the North China block," Journal of Asian Earth Sciences, vol. 26, no. 6, pp. 637-648, 2006.

[21] Y. S. Geng, X. W. Zhou, X. M. Wu, and X. W. Zzhou, "Late -Paleoproterozoic granite events and metamorphic basement in Alxa area: evidence from geochronology," Acta Petrologica, vol. 26, no. 4, pp. 1159-1170, 2010.

[22] Y. S. Geng and X. W. Zhou, "Early Permian magmatic events in the Alxa metamorphic basement: evidence from geochronology," Acta Petrologica Sinica, vol. 28, no. 9, pp. 26672685, 2012.

[23] J. H. Gong, J. X. Zhang, Z. Q. Wang, D. S. Wang, and X. F. Du, "Detrital zircon age characteristics of quartzites from Nuoergong group in eastern Alxa block: provenance and geological significance," Acta Petrologica et Mineralogica, vol. 36, no. 1, pp. 1-19, 2017.

[24] Y. S. Geng, X. S. Wang, Q. H. Shen, and C. M. Wu, "Re-determination of the Alxa Group in the Precambrian Metamorphic Basement in the Alxa area, Inner Mongolia," Chinese Geology, vol. 33, no. 1, pp. 138-145, 2006.

[25] Y. S. Geng, X. S. Wang, Q. H. Shen, and C. M. Wu, "Chronology of the Precambrian metamorphic series in the Alxa area, Inner Mongolia," Chinese Geology, vol. 34, no. 2, pp. 251261, 2007.

[26] J. H. Gong, J. X. Zhang, S. Y. Yu, H. K. Li, and K. J. Hou, "Ca. $2.5 \mathrm{Ga}$ TTG rocks in the western Alxa block and their implications," Chinese Science Bulletin, vol. 57, no. 31, pp. 4064-4076, 2012.

[27] J. H. Gong, J. X. Zhang, and S. Y. Yu, "The origin of Longshoushan Group and associated rocks in the southern part of the Alxa block: constraint from LA-ICP-MS U-Pb zircon dating," Acta Petrologica et Mineralogica, vol. 30, no. 5, pp. 795818, 2011.

[28] S. N. Lu, H. F. Yu, W. Jin, H. K. Li, and J. K. Zheng, "Microcontinents on the eastern margin of Tarim paleocontinent," Acta Petrologica et Mineralogica, vol. 21, no. 4, pp. 317-326, 2002.

[29] S. Wu, J. Hu, M. Ren, W. Gong, Y. Liu, and J. Yan, “Petrography and zircon $\mathrm{U}-\mathrm{Pb}$ isotopic study of the Bayanwulashan Complex: constrains on the Paleoproterozoic evolution of the Alxa block, westernmost North China Craton," Journal of Asian Earth Sciences, vol. 94, pp. 226-239, 2014.

[30] C. Liu, G. Zhao, F. Liu, and J. Shi, "Late Precambrian tectonic affinity of the Alxa block and the North China Craton: evidence from zircon $\mathrm{U}-\mathrm{Pb}$ dating and $\mathrm{Lu}-\mathrm{Hf}$ isotopes of the Langshan Group," Precambrian Research, vol. 326, pp. 312 332, 2019. 
[31] J. L. Luo, X. S. Wei, J. L. Yao, X. S. Liu, and X. H. Liu, "Provenance and depositional facies controlling on the Upper Paleozoic excellent natural gas-reservoir in northern Ordos basin, China," Geological Bulletin of China, vol. 29, no. 6, pp. 811820, 2010.

[32] Z. Z. Wang, B. F. Han, L. X. Feng, and B. Liu, "Geochronology, geochemistry and origins of the Paleozoic-Triassic plutons in the Langshan area, western Inner Mongolia, China," Journal of Asian Earth Sciences, vol. 97, pp. 337-351, 2015.

[33] W. Dan, X. H. Li, Q. Wang, X. C. Wang, D. A. Wyman, and Y. Liu, "Phanerozoic amalgamation of the Alxa block and North China Craton: evidence from Paleozoic granitoids, $\mathrm{U}-\mathrm{Pb}$ geochronology and $\mathrm{Sr}-\mathrm{Nd}-\mathrm{Pb}-\mathrm{Hf}-\mathrm{O}$ isotope geochemistry," Gondwana Research, vol. 32, pp. 105-121, 2016.

[34] J. Gong, J. Zhang, Z. Wang, S. Yu, H. Li, and Y. Li, “Origin of the Alxa block, western China: new evidence from zircon U-Pb geochronology and Hf isotopes of the Longshoushan complex," Gondwana Research, vol. 36, pp. 359-375, 2016.

[35] J. Hu, W. Gong, S. Wu, Y. Liu, and S. Liu, "LA-ICP-MS zircon $\mathrm{U}-\mathrm{Pb}$ dating of the Langshan Group in the northeast margin of the Alxa block, with tectonic implications," Precambrian Research, vol. 255, pp. 756-770, 2014.

[36] H. L. Luo, T. R. Wu, and Y. Li, "Geochemistry and SHRIMP dating of the Kebu massif from Wulatezhongqi, Inner Mongolia: evidence for the Early Permian underplating beneath the North China Craton," Acta Petrologica Sinica, vol. 23, no. 4, pp. 755-766, 2007.

[37] J. H. Gong, X. J. Zhang, Z. Q. Wang, S. Y. Yu, D. S. Wang, and $\mathrm{H}$. Zhang, "Zircon U-Pb dating, Hf isotopic and geochemical characteristics of two suites of Gabbros in the Beidashan region, Western Alxa block: its implications for evolution of the central Asian Orogenic Belt," Acta Geologica Sinica, vol. 92, no. 7, pp. 1369-1388, 2018.

[38] L. A. Solari, J. D. Keppie, F. Ortega-Gutiérrez, K. L. Cameron, R. Lopez, and W. E. Hames, "990 and 1100 Ma Grenvillian tectonothermal events in the northern Oaxacan Complex, southern Mexico: roots of an orogen," Tectonophysics, vol. 365, no. 1-4, pp. 257-282, 2003.

[39] Y. S. Geng, Y. S. Wang, X. S. Wang, Q. H. Shen, and C. M. Wu, "Discovery of Neoproterozoic Jinningian deformed granite in Alxa area and its geological significance," Acta Petrologica et Mineralogica, vol. 21, no. 4, pp. 412-420, 2002. 